\title{
Effects of Guided Inquiry and Task Hierarchy Analysis Model in Cooperative Learning Strategy on Chemistry Students' Performance in Imo State
}

\author{
Nwafor Chimuanya Leonard \\ Dr. (Mrs) A. U Nwanekezi \\ Department of Curriculum Studies and Educational Technology, \\ Faculty of Education, University of Port Harcourt, Rivers State, Nigeria
}

URL:http://dx.doi.org/10.19044/esj.2018.v14n25p54

\begin{abstract}
The study investigated the effects of guided inquiry and task hierarchy analysis model in cooperative learning strategy on Chemistry students' performance in Nwangele Local Government Area, Imo State. The study adopted Pretest Posttest non-equivalent quasi-experimental design. One hundred and sixty-three Chemistry students from six public schools purposively selected participated in the study. Chemistry Performance Test on Acid-Base Reactions (CPTABR) which also tested retention with a reliability index of 0.75 was developed, validated and used for data collection. Research questions were answered using mean and Standard deviation, while the null hypotheses were tested using Analysis of Covariance at 0.05 significance level. The result revealed that Guided Inquiry Learning Strategy (GILS) and Task Hierarchy Analysis Model (THAM) in Cooperative Learning Strategy (CLS) proved to be more effective than lecture method (LM) in understanding of Acid-Base Reactions. It was recommended that Guided Inquiry Learning Strategy (GILS) and Task Hierarchy Analysis Model (THAM) in Cooperative Learning Strategy (CLS) should be used by Chemistry teachers to teach AcidBase Reactions to enhance students' performance and retention in Chemistry.
\end{abstract}

Keywords: Guided Inquiry, Task Hierarchy Analysis Model, Cooperative Learning Strategy Chemistry and Performance.

\section{Introduction}

The wealth, influence and power of any nation depend on her capacity and capability to utilize Science and technology for socio-economic development. It is therefore interesting to say that Science and Technology are the pivot upon which national development revolve. The growth in the field of Science and Technology encourages a better economy of every nation 
especially a developing country like Nigeria. As Science and Technology grow increasingly, the teaching of Science subjects especially Chemistry at the secondary school level of education continues to call for $21^{\text {st }}$ century innovative and interactive strategies for easy implementation of Science education curriculum. Without Science education, Information and Communication Technology (ICT) would almost be impossible. Chemistry as a core science subject plays a very crucial role in scientific and technological development. This is evidenced on the impact of Chemistry on Engineering, Medicine, Architecture and other Science disciplines. Researchers like Isidor (2012), Kalu (2014) and Nkemka (2015) had employed different strategies such as demonstration method, discussion method and explorative and field trip approach in teaching Chemistry concepts. Yet, students' performance in Chemistry is still dwindling. Meanwhile, the Federal Republic of Nigeria (FRN, 2014) in her Chemistry curriculum document, stipulated that Chemistry should be taught in such a way that will help the students acquire adequate laboratory and field skills, meaningful and relevant knowledge in Chemistry through field studies, guided-discovery, laboratory techniques and skills

In line with the above, Chemistry teachers are expected to ensure effective and meaningful teaching of Chemistry concepts to the students. Nevertheless, the poor and inappropriate method adopted by Chemistry teachers during classroom instruction has led to the poor performance of students in external examinations. In an attempt to help students learn and better understand Acid-Base Reactions, guided inquiry and the task hierarchy analysis model as developed by Gagne (1967) which specified learning from simple to complex and from known to unknown in a cooperative learning strategy has been employed in the study.

Guided inquiry learning strategy is an approach in which students are giving activities through which they develop knowledge and understanding of concepts, ideas and course by engaging in students centered hands-on - mindson task while the teacher functions as the facilitator. The guided inquiry process puts the emphasis on scientist in "student-scientist." The primary objective of guided inquiry is to promote learning through student investigation (Coffman and Riggs, 2006). Cornel (2014) investigated the effect of inquiry based laboratory activities in the enhancement of students' performance in practical Chemistry in Australian high school. The study reported that students' performance was better in the self-directed learning experience. Ugwu (2015) also conducted a research on the impact of guided inquiry instructional strategy on Chemistry students' performance in Abia State. The result obtained showed that SS1 Chemistry students taught using guided inquiry instructional strategy recorded high academic performance in the mean scores than those taught using conventional method. Adeyemi (2016) asserted that many science educators believe that it is unlikely for students to 
be able to discover in 90-120 minutes, what took great scientists many years to find. Guided inquiry, where the teacher provides some intervention is the type that is recommended in the Nigerian Junior Secondary School Integrated Science as well as the senior secondary school Chemistry, Biology and Physics curricula (NERDC,2009), Adeyemi (2016).

Crandall, Klein, and Hoffman, (2006) defined hierarchical task analysis (HTA) as a widely used type of task analysis where a high-level task is decomposed into a hierarchy of subtasks. This means that (HTA) is sometimes referred to as a hierarchical decomposition. This hierarchical analysis was adopted in cooperative learning. Cooperative learning strategy is a strategy which organizes students in small groups so that they can work together to maximize each other's shared knowledge. Cooperative learning changes students' and teachers' roles in the classroom. Cally (2015) clearly asserted that students showed improvement in their academic interactions and learning styles as a result of cooperative learning strategy. Uloaku (2015) asserted that students' performance and retention increases when they engaged using interactive strategies. This is so because in a cooperative learning strategy the students play the major role in their learning. The concept of AcidBase Reactions is a difficult concept for students at the senior secondary two level of education. It therefore requires the application of innovative teaching and learning strategies, approaches and well-designed laboratory and instructional materials in order to achieve the desired objectives. It was based on this conviction that the study investigated guided inquiry and task hierarchy analysis model in Cooperative learning strategy on Chemistry students' performance and retention in Imo State, Nigeria.

\section{Statement of the Problem}

Under-performance of Chemistry students in external examinations has remained worrisome to Chemistry teachers and educators. This ugly outcome is not far from the poor and inappropriate instructional strategies adopted by Chemistry teachers which are major challenges facing the effective implementation of Chemistry curriculum (Esogwa, 2015). Research findings have also shown that inadequate laboratory facilities and lack of exposure of the students to laboratory practical exercise has been one of the factors that contribute to poor performance in Chemistry (Ehirim,2016). Consequently, this paper developed methods of delivery of instruction in Chemistry by exposing SS2 students to innovative instructional methods such as Guided Inquiry and Task Hierarchy Analysis Model (THAM) in Cooperative Learning Strategy (CLS) with the view of enhancing students' performance and retention in Acid-Base Reactions in Chemistry. 


\section{Objectives of the Study}

1. Determine the effect of guided inquiry learning strategy (GILS) on SS2 students' performance in acid-base reactions

2. Investigate the effect of task hierarchy analysis model (THAM) in cooperative learning strategy (CLS) on SS2 students' performance in acid-base reactions

\section{Research Questions}

The study sought to provide answers to the following research questions

1. What is the effect of guided inquiry learning strategy (GILS) on SS2 students' performance in acid-base reactions?

2. What is the effect of task hierarchy analysis model (THAM) in cooperative learning acid-base reactions? strategy (CLS) on SS2 students' performance in

Hypotheses: The following null hypotheses guided the study:

Ho1: There is no significant difference between the mean performance of SS2 students taught acid-base reactions using Guided Inquiry Learning Strategy (GILS) and Lecture Method (LM)

$\mathrm{Ho}_{2}$ : There is no significant difference between the mean performance of SS2 students taught acid-base reactions using THAM in CLS and LM

\section{Methodology}

The study adopted quasi-experimental design involving pretest and posttest non-equivalent group. One control group and two experimental groups in public schools were used. The sample size consisted of one hundred and sixty-three SS2 Chemistry students in three intact classes. The researchers took advantage of SS2 students because they are preparing for the School Certificate Examination (SSSCE) in 2019. Chemistry Performance Test on AcidBase Reactions (CPTABR) containing 30 objective questions was used as instrument for data collection. The instrument was validated by two experts in Department of Curriculum Studies and Educational Technology, University of Port Harcourt, Nigeria. The final draft was subjected to a reliability test using Pearson Product Moment Correlation formula; an index of 0.75 was obtained. Both groups were pretested prior to the commencement of the study with the instrument to ascertain baseline knowledge.

The experimental groups were taught using Guided Inquiry Learning Strategy and Task Hierarchy Analysis Model in Cooperative Learning Strategy. The control group was taught the same concept using the lecture method. Data obtained were analyzed using mean scores and standard deviation for the research questions while Analysis of Co-variance (ANCOVA) was used to test the hypotheses at 0.05 significance level. 


\section{Results}

The results are presented in the following tables

Research Question One: What is the effect of guided inquiry learning strategy (GILS) on SS2 students' performance in acid-base reactions?

Table 1: Mean and Standard deviation on performance of students in Acid-base Reactions using GILS and LM

\begin{tabular}{ccccccc}
\hline Group & N & Pretest & SD & Posttest & SD & $\begin{array}{c}\text { Mean } \\
\text { Difference }\end{array}$ \\
\hline GILS & 57 & 12.21 & 3.49 & 21.92 & 6.573 & 9.71 \\
LM & 51 & 12.92 & 4.52 & 14.76 & 5.60 & 1.84 \\
\hline
\end{tabular}

From table 1 above, it can be observed that students taught acid-base reactions using guided inquiry learning strategy had a score of 12.21 prior to treatment administration, while after treatment their post-test score was 21.92. For students in the control group who were taught using lecture method, their pretest mean performance was 12.92 , while their post-test mean performance was 14.76. This result revealed that the mean difference for students in experimental group was 9.71, while for the control group was 1.84 . These results suggested that guided inquiry learning strategy has a greater effect in students' performance in acid-base reactions than lecture method.

Research Question Two: What is the effect of task hierarchy analysis model (THAM) in cooperative learning strategy (CLS) on SS2 students' performance in acid-base reactions?

Table 2: Mean and Standard deviation on performance of students in Acid-base Reactions using THAM in CLS

\begin{tabular}{|c|c|c|c|c|c|c|}
\hline Group & $\mathbf{N}$ & Pretes & SD & Posttest & SD & $\begin{array}{c}\text { Mean } \\
\text { Difference }\end{array}$ \\
\hline THAM in CLS & 55 & 13.96 & 3.57 & 21.10 & 7.20 & 7.14 \\
\hline LM & 51 & 12.92 & 4.52 & 14.76 & 5.60 & 1.84 \\
\hline
\end{tabular}

From the table 2 above, it can be observed that the pretest mean performance of experimental group taught using THAM in Cooperative learning strategy was 13.96 while their post-test mean performance score was 21.10. For the control group taught using the lecture method, students had a pretest score of 12.92 and a post-test score of 14.76. Considering the values, it can be seen that the mean difference between the pretest and posttest mean performance of experimental group and the control group were 7.14 and 1.84 respectively. This result suggests that THAM in Cooperative learning strategy has a greater effect in the mean performance of students in acid-base reaction than lecture method.

Ho1: There is no significant difference between the mean performance of SS 2 students taught acid-base reactions using GILS and LM 
Table 3 Analysis of Covariance (ANCOVA) of Performance of SS 2 students taught acid-base reactions using GILS and LM

\begin{tabular}{ccrrrr}
\hline Source & \multicolumn{1}{c}{$\begin{array}{l}\text { Type III } \\
\text { Sum of } \\
\text { Squares }\end{array}$} & df & \multicolumn{1}{c}{$\begin{array}{c}\text { Mean } \\
\text { Square }\end{array}$} & F & Sig. \\
& $1502.556^{\mathrm{a}}$ & 2 & 751.278 & 20.382 & .000 \\
Corrected & & & & & \\
Model & 2212.391 & 1 & 2212.391 & 60.023 & .000 \\
Intercept & 120.684 & 1 & 120.684 & 3.274 & .073 \\
PreP & 1444.244 & 1 & 1444.244 & 39.183 & .000 \\
Group & 3870.212 & 105 & 36.859 & & \\
Error & 42521.000 & 108 & & & \\
Total & 5372.769 & 107 & & & \\
Corrected Total & &
\end{tabular}

The result in the table 3 above revealed that the F-value of 39.183 obtained at 1 and 105 degrees of freedom had an associated p-value of .000, which is lesser than the chosen alpha of 0.05 , it can be stated that GILS had a significant effect on the mean performance of students in acid-base reactions. The null hypothesis was therefore rejected.

Hypothesis Two: There is no significant difference between the mean performance of SS2 students taught acid-base reactions using task hierarchy analysis mode in cooperative learning strategy and lecture method

Table 4 Analysis of Covariance (ANCOVA) of Performance of SS 2 students taught acid-base reactions using THAM in CLS and LM

\begin{tabular}{ccrrrr}
\hline Source & $\begin{array}{c}\text { Type III } \\
\text { Sum of } \\
\text { Squares }\end{array}$ & df & \multicolumn{1}{c}{$\begin{array}{c}\text { Mean } \\
\text { Square }\end{array}$} & F & Sig. \\
& $1145.148^{\mathrm{a}}$ & 2 & 572.574 & 13.726 & .000 \\
Corrected & & & & & \\
Model & 1966.662 & 1 & 1966.662 & 47.147 & .000 \\
Intercept & 80.009 & 1 & 80.009 & 1.918 & .169 \\
Prep & 974.532 & 1 & 974.532 & 23.362 & .000 \\
Group & 4296.513 & 103 & 41.714 & & \\
Error & 40002.000 & 106 & & & \\
Total & 5441.660 & 105 & & & \\
Corrected Total & & & & & \\
\hline
\end{tabular}

From data analysis using (ANCOVA) in the table 4 above, it can be seen that the F-value of 23.362 obtained at 1 and 103 degrees of freedom had a corresponding p-value of 0.000 , which is lesser than the chosen alpha of 0.05 for the study. From this value, it can be stated that there was a significant effect of THAM in Cooperative learning strategy on the mean performance of students in acid-base reactions. The null hypothesis was therefore rejected.

\section{Discussion of Finding}

Table 1 revealed the mean difference of students taught using guided inquiry learning strategy to be 9.71 , while the mean difference of students 
taught with lecture method is 1.84 . This result suggested that guided inquiry learning strategy has a greater effect on students' performance in acid-base reactions than lecture method. The result in table 3 confirmed the statistical significance of the observed result in table 1. Hence, GILS had a significant effect on the mean performance of students in acid-base reactions. The null hypothesis was therefore rejected $(.000<0.05)$. This finding is in agreement with the statement of Coffman and Riggs (2006) that guided inquiry promotes learning through students' investigation. Furthermore, Cornel (2014) investigated the effect of inquiry based laboratory activities in the enhancement of students' performance in practical Chemistry and observed that students' performance was better in the self-directed learning experience. Ugwu (2015) in another study, showed that SS1 Chemistry students taught using guided inquiry instructional strategy recorded high academic performance in the mean scores than those taught using conventional method.

The result in table 2 showed that, with the mean difference of 7.14, the students exposed to THAM in CLS had the highest academic performance than the students exposed to lecture method with mean difference of 1.84 respectively. This result proved that THAM in Cooperative learning strategy has a greater effect on the mean performance of students in acid-base reactions than lecture method. From the Analysis of Covariance in the table 4, it can be stated that there was a significant effect of THAM in Cooperative learning strategy on the mean performance of students in acid-base reactions. This implies that the null hypothesis was rejected $(.000<0.05)$. This result agreed with the finding of Cally (2015) who clearly asserted that students showed improvement in their academic interactions and learning styles as a result of cooperative learning strategy. Uloaku (2015) also confirmed that students' performance increased when they are engaged interactive strategies. This is true because in a cooperative learning strategy students actively participate in their learning.

\section{Conclusion}

The study investigated the effects of guided inquiry and task hierarchy analysis model in cooperative learning strategy on Chemistry students' performance in Nwangele Local Government Area, Imo State. The study is an extension in the use of $21^{\text {st }}$ century innovative and learner centered instructional strategies that encourage active participation, cognitive involvement and higher level thinking skills of students. The study showed that Guided Inquiry Learning Strategy (GILS) and Task Hierarchy Analysis Model (THAM) in Cooperative Learning Strategy (CLS) proved to be more effective than lecture method (LM) in understanding of Acid-Base Reactions. The lecture method (conventional method) of teaching Chemistry was found weak in improving students' performance. The study also provided empirical 
evidence on the relative efficacy of interactive strategies in enhancing the teaching and learning outcomes in Chemistry. Based on the findings of the study, it was therefore concluded that the use of guided inquiry learning strategy and task hierarchy analysis model in cooperative learning strategy has significant effect on the students' academic performance.

\section{Recommendations}

The study recommended that:

1. Guided Inquiry Learning Strategy (GILS) and Task Hierarchy Analysis Model (THAM) in Cooperative Learning Strategy (CLS) should be used by Chemistry teachers to teach Acid-Base Reactions so as to enhance students' performance and retention in Chemistry.

2. Chemistry teachers on the job should be retrained to improve on these innovative and interactive methods of instruction. This can be done through seminars, conferences and workshops organized by both government and non-government agencies like the science teachers association of Nigeria (STAN).

\section{References:}

1. Adeyemi, A. S. (2016). Effect of guided inquiry learning on Physics students' performance in Ebonyi Sate. Journal of Educational Issues, 30 (2), 44-57

2. Cally, E.A., (2015). Effect of Think-pair-share on Biology students' performance in chemical change in Abia State, Journal of Management and Social Sciences 5(1\&2), 12-25

3. Coffman, M \& Riggs, L (2006). The Virtual Vee Map: A Template for internet Inquiry, Journal of College Science Teaching, September, 3229

4. Cornel, F.O. (2014). Effect of guided inquiry approach on Chemistry students' Performance and interest level in Redox Titration in Secondary Schools in Owerri metropolis, Imo State. Journal of Research in Eduction, 4(2), 27-41

5. Crandall, B., Klein, G., \& Hoffman, R. R. (2006). Working Minds: A Practitioner's Guide to Cognitive Task Analysis. MIT Press. "This is an important book for the engineering of complex systems and information technology systems."

6. Ehirim, D.S (2016). Factors affecting effective teaching of Chemistry in private and public secondary schools in Rivers State. Journal of Scientific Research in Eduction, 5(2), 22-32

7. Esogwa, J.L., (2015). Effect of Jigsaw Cooperative Learning Instructional Approach on Mathematics Students Academic 
Achievement in Anambra State. Educational Research and Review, 3 (1), 33-37.

8. Federal Republic of Nigeria, (2014). National Policy on Education, Lagos, $4^{\text {th }}$ Edition, NERDC Press.

9. Gagne, R.M (1967). The Conditions of Learning (4th Ed.). New York: Holt, Rinehart Winston.

10. Isidor, E.A (2015). Effect of Demonstration Teaching Method on Biology students' performance and interest in Science Process Skills Acquisition Among senior secondary students in Abak LGA, AkwaIbom. Journal of Education Foundation (JEF), 1 (1), 12-14

11. Kalu, M.U. (2014). Impact of Explorative Strategy in teaching Sciences: A need for paradigm shift in pedagogy, Journal of Science and Technical Education, 1 (2) 92-101

12. Nkemka, E.I (2015). Effects of Discussion and Demonstration methods of teaching on Academic Performance of Students in Social Studies in Onitsha metropolis, Anambra State. Journal of Educational Research and Review.7(3), 31-33.

13. Ugwu, S.H (2015). Impact of Guided Inquiry Instructional on Chemistry students' Performance in Ikwuato Local Government Area, Abia State. Nigeria. Journal of Science and Technical Education, 4(1), 112-125

14. Uloaku, E.I (2015). Think-pair-share Cooperative Learning Strategy and Physics students' academic achievement in Abia State, Nigeria. International Journal of Educational Research and Technology, 1(1), 49-57. 